\title{
OPTIMASI SEDIAAN SALEP MINYAK CENGKEH (SYZIGIUM AROMATICUM) DALAM BASIS LARUT AIR
}

\author{
Rani Prabandari ${ }^{1)}$, Adita Silvia ${ }^{2)}$ \\ ${ }^{1), 2)}$ Program Studi Farmasi Sekolah Tinggi Ilmu Kesehatan Harapan Bangsa Purwokerto \\ ${ }^{1)}$ raniprabandario@shb.ac.id ${ }^{2}$ aditasilvia@shb.ac.id
}

\begin{abstract}
Abstrak
Minyak atsiri bunga cengkeh (Syzygium aromaticum) dengan senyawa aktif eugenol telah banyak diteliti dan diketahui berkhasiat sebagai antiinflamasi, dan penelitian lanjutan terkait formulasinya terus dilakukan. Formula yang dikembangkan pada penelitian ini adalah bentuk sediaan topikal salep dengan menggunakan basis larut air (enhancer asam oleat dan propilen glikol). Penelitian ini bertujuan untuk mengetahui sifat fisik dan daya iritasi dari sediaan salep minyak atsiri bunga cengkeh (MABC) jika digunakan basis hidrokarbon. Salep dibuat dengan metode peleburan dengan konsentrasi MABC 5\% (F1), $10 \%$ (FII) dan 15\% (FIII). Salep dari ketiga formula ini kemudian dievaluasi sifat fisiknya, meliputi daya sebar, daya lekat dan $\mathrm{pH}$. Hasil uji statistik dengan uji LSD menunjukkan terdapat perbedaan yang signifikan antar formula. Semakin tinggi konsentrasi MABC, menyebabkan makin besar daya sebar (p0,05). Hasil uji iritasi Simplex Lattice Design menunjukkan pula bahwa salep basis larut air dengan konsentrasi MABC 5\%, $10 \%$ dan $15 \%$ tidak menimbulkan efek iritasi.
\end{abstract}

Kata kunci : Syzygium aromaticum, basis salep larut air, antiinflamasi.

\begin{abstract}
The clove flower essential oil (Syzygium aromaticum) with the active compound eugenol has been widely investigated and is known to be efficacious as an anti-inflammatory agent, and further research on its formulation continues. The formula developed in this study was a topical ointment dosage form using a water soluble base (oleic acid enhancer and propylene glycol). This study aims to determine the physical and irritant properties of the clove flower essential oil ointment (MABC) if a hydrocarbon base is used. The ointment is made by the smelting method with a concentration of 5\% (F1), 10\% (FII) and 15\% (FIII). The ointments of the three formulas were then evaluated for their physical properties, including dispersion, adhesion and $\mathrm{pH}$. The results of statistical tests with the LSD test showed that there were significant differences between formulas. The higher the concentration of MABC, the greater the spread (p0.05). The results of the Simplex Lattice Design irritation test also show that water-soluble base ointment with a concentration of 5\%, 10\% and $15 \%$ MABC does not cause an irritating effect.
\end{abstract}

Keywords: Syzygium aromaticum, base of water soluble ointment, anti-inflammatory. 


\section{PENDAHULUAN}

Minyak cengkeh merupakan minyak atsiri yang berasal dari tanaman cengkeh (Syzygium aromaticum) yang memiliki aktivitas biologis karena mengandung senyawa eugenol dan dikenal memiliki sifat farmakologi seperti hipotermia, antioksidan, anestesi lokal dan antiinflamasi. Penelitian telah menunjukkan bahwa eugenol menekan sinyal TNF $\alpha$ dan ekspresi COX-2, yang menunjukkan potensinya sebagai agen anti-inflamasi (Chainy dkk., 2000). Berdasarkan potensi minyak atsiri bunga cengkeh dengan bahan aktif eugenol sebagai anti inflamasi, maka perlu dikembangkan bentuk sediaan yang acceptable dan dapat diterima dengan baik oleh masyarakat luas. Pengembangan formula terhadap minyak atsiri bunga cengkeh $(\mathrm{MABC})$ terus dilakukan. Salah satu cara yang dapat dilakukan untuk mengembangkan formula dari MABC yaitu dengan menambahkan suatu enhancer pada formulasi sediaan.

Metode yang digunakan pada penelitian ini untuk mengetahui komposisi optimum asam oleat dan propilen glikol adalah metode Simplex Lattice Design. Metode Simplex Lattice Design merupakan metode untuk menentukan proporsi komponen teroptimum yang disesuaikan dengan variabel atau respon yang telah ditentukan. Metode Simplex Lattice Design juga merupakan salah satu dari beberapa teknik yang digunakan dalam prosedur optimasi formulasi yang berguna dalam perencanaan sediaan obat (Bolton, 1997).

Berdasarkan latar belakang tersebut, peneliti ingin melihat aktivitas anti inflamasi dari sediaan salep basis larut air Minyak Atsiri Bunga Cengkeh (MABC) (Syzygium aromaticum) yang telah terstandarisasi dengan penambahan enhancer. Penelitian ini diharapkan dapat memberikan efek sebagai antiinflamasi namun tidak memberikan efek iritasi.

\section{METODOLOGI}

Penelitian ini dilaksanakan di Laboratorium Kimia Farmasi, Laboratorium Teknologi Farmasi Program Studi S1 Farmasi Sekolah Tinggi Ilmu Kesehatan Harapan Bangsa Purwokerto Bahan yang digunakan adalah minyak atsiri bunga cengkeh yang didapat dari Pasar Pamijen Baturaden, Polietilen glikol (PEG) 400 (derajat farmasetis) dan PEG 4000 (derajat farmasetis), crotton oil (Sigma), mencit jantan galur BALB/c umur 2-3 bulan dengan berat badan 20-30 g, perontok rambut (Veet) dan mikroskop (Olympus).

Penelitian ini merupakan penelitian eksperimental dengan membandingkan 
beberapa perbandingan konsentrasi dan dilakukan evaluasi sediaan yang enhancer asam oleat dan propilen glikol meliputi uji transport eugenol dalam pada sediaan salep basis serap minyak atsiri minyak atsiri melewati membran kulit, uji bunga cengkeh terhadap uji anti inflamasi sifat fisik sediaan, dan uji daya iritasi. berdasarkan metode Simplex Lattice design,

HASIL DAN PEMBAHASAN

Pembuatan salep minyak atsiri bunga

Metode pembuatan formula salep basis cengkeh dalam basis larut air dilakukan dengan larut air minyak atsiri bunga cengkeh cara sebagai berikut: konsentrasi minyak atsiri menggunakan metode peleburan. Salep bunga cengkeh yang digunakan dalam pembuatan dibuat dengan memanaskan PEG 400 dan salep basis larut air adalah konsentrasi sebesar PEG 4000 kemudian diaduk sampai 5\%, 10\%, 15\%. Selanjutnya dalam formula terbentuk massa yang kental dan homogen tersebut ditambahkan enhancer asam oleat dan lalu dimasukkan enhancer (asam oleat dan propilen glikol yang komposisi optimumnya telah propilen glikol) dan diaduk sampai homogen. ditentukan berdasarkan metode Simplex Lattice Minyak atsiri ditambahkan ketika sudah Design seperti yang disajikan pada Tabel 1. dingin kemudian dicampur hingga homogen.

Tabel 1. Formula sediaan salep basis larut air minyak atsiri bunga cengkeh de: penambahan enhancer asam oleat dan propilen glikol

\begin{tabular}{llll}
\hline Bahan & Formula I (\%) & Formula II (\%) & Formula III (\%) \\
\hline MABC Terstandar & 5 & 10 & 15 \\
Asam oleat & 85,5 & 81 & 76,5 \\
Propilen glikol & 0 & 5 & 10 \\
\hline
\end{tabular}

*MABC: Minyak Atsiri Bunga Cengkeh

Keterangan : Formula I (FI) formula dengan komposisi asam oleat $100 \%$ danpropilen glikol $0 \%$

Formula II (FII) formula dengan komposisi asam oleat 50\% dan propilen glikol $50 \%$

Formula III (FIII) formula dengan komposisi asam oleat $0 \%$ dan propilen glikol $100 \%$

Uji validasi metode Simplex Lattice perbandingan AO 30\% : PG 70\%. Uji Design peneliti menggunakan komposisi formula optimum yaitu dengan transport eugenol. Parameter transport 
eugenol ialah dengan melihat nilai fluks dan permeabilitas pada formula uji dengan perbandingan $\mathrm{AO} 30 \%$ dan $\mathrm{PG} 70 \%$ berdasarkan perhitungan respon total. Hasil dari uji optimasi perbandingan tersebut diharapkan tidak berbeda bermakna. Untuk membandingkan hasil

Gambar 4. Hasil Respon Total Penentuan Formula Optimum pada Opti Komposisi Enhancer Asam Oleat dan Propilen Glikol pada sec salep basis larut air Minyak Atsiri Bunga Cengkeh (Syzi aromaticum) dengan metode Simplex Lattice Design

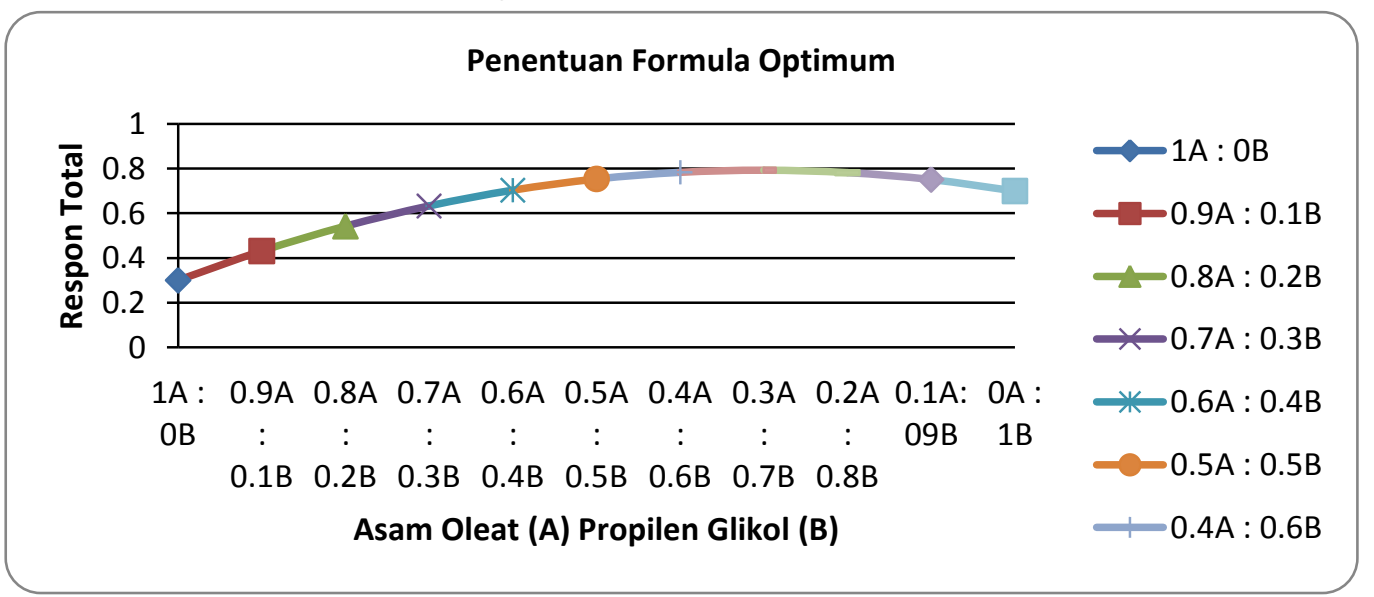

Tabel 3. Hasil Analisis Statistik Validasi Metode SLD Optimasi Komp Enhancer Asam Oleat dan Propilen Glikol pada sediaan salep basis s Minyak Atsiri Bunga Cengkeh (Syzigium aromaticum) dengan $\mathrm{m} \epsilon$ Simplex Lattice Design

\begin{tabular}{lll}
\hline Formula Optimum & Fluks & Permeabilitas \\
\hline SLD vs Uji Validasi & $\mathrm{P}<0.05$ & $\mathrm{P}<0.05$ \\
\hline
\end{tabular}

Hasil Analisis Statistik Validasi metode SLD disajikan pada table 3. Adanya perbedaan yang signifikan antara hasil uji SLD dan hasil uji validasi dapat disebabkan oleh beberapa faktor salah satunya karena perbedaan tebal kulit membran sehingga mempengaruhi kecepatan absorpsi obat. Menurut Aiache (1982) kecepatan obat untuk terabsopsi kedalam kulit dipengaruhi obat tebalnya membran kulit, semakin tebal kulit maka semakin kecil obat yang 
terabsopsi kedalam kulit, begitu pula sebaliknya.

\section{KESIMPULAN}

Adanya perbedaan yang signifikan antara hasil uji SLD dan hasil uji validasi dapat disebabkan oleh beberapa faktor salah satunya karena perbedaan tebal kulit membran sehingga mempengaruhi kecepatan absorpsi obat.

\section{SARAN}

Perlu dilakukan penelitian lebih lanjut tentang evaluasi pada toksisitas dari sediaan salep basis larut air sehingga bisa lebih optimal dalam mengobati inflamasi dan untuk mengevaluasi batas keamanannya jika digunakan dalam jangka panjang.

\section{DAFTAR PUSTAKA}

Ashari, S. 1995. Hortikultura, Aspek Budidaya. Universitas Indonesia. Jakarta

Asmawati, N., Purwati P. dan HandayaniR. S.2015. Efektivitas Rebusan Seledri Dalam Menurunkan Tekanan Darah Pada Lansia Penderita Hipertensi Di Posyandu Lansia Kelurahan Pajar Bulan Kecamatan Way Tenong Lampung Barat. Jurnal Kesehatan. 4 (2): 130-136.

Badan Pengawas Obat dan Makanan Repoblik Indonesia. 2004. Volume I. BPOM RI. Jakarta.

Husen, R. W. M., Yamlean P. V. Y. dan Citraningtyas G. 2015. Formulasi Dan
Badan Pengawas Obat dan Makanan Repoblik Indonesia. 2008. Seledri sebagai Bahan Obat Alam.

Badan Standarisasi Nasional. 1992. SNI 01-28911992. Cara Uji Makanan dan Minuman. Jakarta.

Badan Standarisasi Nasional. 2013. SNI 01-3544: 2013. Sirup. Jakarta.

Dalimartha, S. 2000. Atlas Tumbuhan ObatIndonesia. Jilid II. PT. Trubus Agriwidya. Jakarta.

Departemen Kesehatan Republik Indonesia. 2008. Materia Medika Indonesia. Cetakan Kelima. Departemen Kesehatan Republik Indonesia. Jakarta.

Djamil, R. dan Wijiastuti E. 2015. Penapisan Fitokimia, Uji Aktivita sekstrak Metanol Herba Seledri, Batang/Daun Ashitaba dan Daun Petroseli (Apiaceae). Dipresentasikan pada rakernas \& PITI AI Universitas Pancasila.Jakarta.

Goldsmith, L. A. dan MerkelC. M. 2001. Sucralose. Di dalam: Nabors LOB, editor. Alternative Sweetener, Ed ke-3, New York.

Goodman, G. 2008. The Pharmacological Basis and Therapeutics. Penerbit Buku Kedokteran EGC. Bandung.

Gunawan, E. dan Simaremare E. S. 2016. Formulasi Sirup Antimalaria Ekstrak Kulit Batang Kayu Susu (Alstonia Scholaris L.) jurnal Pharmacy. 13 (1): 1-9. 
Evaluasi Sirup Ekstrak Daun Sidaguri (Sida rhombifolia L.). Pharmacon jurnal Ilmiah Farmasi - Unsrat. 4 (3): 134138.

Kementerian Kesehatan Republik Indonesia. 2013. Riset Kesehatan Dasar. Badan Penelitian dan Pengembangan Kesehatan. Jakarta.

Manitto, P. 1981. Biosynthesis of Natural Products. Ellis Horwood Limited Publisher, Chicester, Ingris.

Masruhen. 2000. Perbandingan Kadar Flavonoid dan Daya Antihipertensi Antara Sari Etanol 50\% Daun Seledri (Apium graveolens L) Dan Biji Seledri Terhadap Tekanan Darah Sistemik Kucing Dianastesi. Skripsi. Fakultas Farmasi. UGM. Yogyakarta.

Muchtadi, D. dan Wijaya, C. H. 1996. Makanan Fungsional: Pengenalan dan Perancangan. Hand-Out Kursus Singkat Makanan Fungsional dan Keamanan Pangan. PAU Pangan dan Gizi. UGM. Yogyakarta.

Nadinah. 2008. Kinetika Inhibisi Ekstrak Etanol Seledri (Apium graveolens L.) dan Fraksinya Terhadap Enzim Xantin Oksidase Serta Penentuan Senyawa Aktifnya. Tesis. Sekolah Pascasarjana, IPB. Bogor.

Palupi, M. R. dan Widyaningsih, T. D. 2015. Pembuatan Minuman Fungsional Liang Teh Daun Salam (Eugenia polyantha) dengan Penambahan Filtrat Jahe dan Filtrat Kayu Secang. Jurnal Pangan dan Agroindustri.. 3(4): 1458-1464.
Liliana,W. 2011. Kajian Pembuatan Teh Herbal dari Seledri (Apium graveolens L.). Skripsi. Fakultas Pertanian. IPB. Bogor.

Rosita, I. I., Munisa,A. N., Kalsum, A.U. dan Rahmawati, A. 2014. Praktikum Kimia Fisika II Viskositas. Universitas Islam Negeri Syarif Hidayatullah.Jakarta.

Saragih, R. 2014. Uji Kesukaan Panelis Pada Teh Daun Torbagun. E-Jurnal Widya Kesehatan dan Lingkungan. 1 (1): 46-52.

Sayuti, N. A. 2015. Respon rasa campuran ekstrak seledri (Apium graveolens L.) dan ekstrak asam jawa (Tamarindus indica) dalam sediaan serbuk effervescent. Jurnal farmasi indonesia. 12 (2): 114-126.

Siswandono dan Soekardjo, B., 2000, Kimia Medisinal, Edisi 2, 228-232, 234, 239, Airlangga University Press, Surabaya.

Soewito. 1991. Bercocok Tanam Seledri. Titik Terang. Jakarta.

Sumaenda, L. (2011). Analisis Kandungan Klorofil Daun Mangga (Mangifera Indica L.) Pada Tingkat Perkembangan Daun Yang Berbeda. Bioslogos. 1 (1): 20-24.

Syahputra, A. R. dan Suhartini M. 2013. Peningkatkan Stabilitas Viskositas Pelumas Hidrolik Dari Kopolimer Lateks Karet Alam-Stirena. Bionatura-Jurnal Ilmu-ilmu Hayati dan Fisik. 15 (1):60-64.

Syamsuhidayat dan Hutapea, J.R., 1991, Inventaris Tanaman Obat Indonesia, 305-306, Departemen Kesehatan 
Republik Indonesia, Badan Penelitian dan Pengembangan Kesehatan, Jakarata.

Tedjasukmana, P. 2012. Tata Laksana Hipertensi Departemen Kardiologi, RS Premier Jatinegara dan RS Grha Kedoya. Jakarta. Indonesia.

Tim Prima Tani. 2011. Petunjuk Teknis Budidaya Seledri. Balai Penelitian Tanaman Sayuran. Bandung.

Tiwari, P., Kumar B., Kaur M., Kaur G. \& Kaur H. (2011). A review: Phytochemical Screening and Extraction. Internationale Pharmaceutica Sciencia, 1(1): 98106.

Wahdah dan Nurul. 2011. Menaklukkan Hipertensid an Diabetes (Mendeteksi, Mencegah dan Mengobati Dengan Cara Medis dan Herbal). Multi Press, Yogyakarta. 